
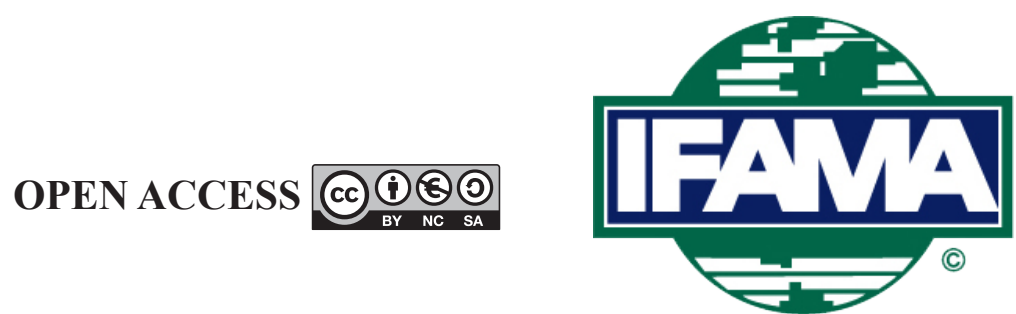

International Food and Agribusiness Management Review

Volume 25, Issue 1, 2022; DOI: 10.22434/IFAMR2020.0193

Received: 20 November 2020 / Accepted: 12 May 2021

\title{
Quantifying differences in alternative food network supply chain activities and their relationship with socio-economic outcomes \\ RESEARCH ARTICLE
}

\author{
Erik Hunter ${ }^{\mathrm{a}}$, Andreas Norrman $^{\oplus \mathrm{b}}$ and Eva Berg ${ }^{\mathrm{c}}$ \\ ${ }^{a}$ Associate Professor, Department of People and Society, Swedish University of \\ Agricultural Sciences, Slottsvägen 5, 23053 Alnarp, Sweden \\ ${ }^{b}$ Professor, ${ }^{c}$ Lecturer, Department of Industrial Management and Logistics, \\ Lund University, Naturvetarvägen 18, 22362 Lund, Sweden
}

\begin{abstract}
Alternative food networks (AFNs) have the potential to enhance and redistribute value in favour of producers and consumers through novel ways of organizing supply chain activities. What is more, AFNs are often characterized by their 'sustainability promise' - or the idea that their networks foster social, ecological or environmental improvements over conventional food networks. Based on a purposive sample of 286 producers across five Swedish AFNs (i.e. community supported agriculture, REKO-rings, farmers' markets, farm stores and food nodes), we explore how differences in how supply chain activities are managed and relate them to profitability, fair wages, cooperation, logistics efforts, happiness and future beliefs. Using a combination of correlation analysis, linear regression and means comparisons, we challenge the notion that AFNs achieve their sustainability promise or enhance value through novel combinations of supply chain activities. Our findings include several key differences in how supply chain management (SCM) activities are organized across AFNs and their variant importance for profitability. Moreover, we find significant differences in happiness across AFNs that are better explained through beliefs about the future than profitability or fair wages. By exploring happiness and profitability, we offer insights into why some AFN actors thrive despite poor economic returns.
\end{abstract}

Keywords: alternative food networks, logistics, supply chain management, agriculture, happiness JEL code: Q13, M10, L66

(ํ)Corresponding author: andreas.norrman@tlog.lth.se 


\section{Introduction}

Alternative food network (AFN) is an umbrella term used to label farmer's markets, community-supported agriculture and other emerging networks of producers, consumers, and other actors that offer alternatives to conventional modes of food supply (Renting et al., 2003). Perhaps what has stimulated the proliferation of AFNs, formed the basis for distinction and captivated the attention of scholars is the 'sustainability promise' or narrative that AFNs do a better job promoting social and environmental change through economically viable and ecologically sound distribution practices (Michel-Villarreal et al., 2019). Related to this is the belief that AFNs have the potential to enhance or redistribute value in favor of small producers and consumers and away from large, conventional producers and intermediaries (Forssell and Lankoski, 2015).

The narrative surrounding the sustainability promise and potential of the AFNs has generated lively debate in the literature. For example, Tregear (2011) believes AFN research is often uncritically accepting of ambiguous concepts and conflates claims of structural properties of food systems with their impact. Instead of pursuing aspirational notions of what AFNs are or adopting normative definitions of what they should be, it was more productive to address why some, but not other AFNs achieved goals related to the sustainability promise and how socio-economic outcomes could be enhanced. Since then, numerous studies have provided empirical nuance and we now know that the sustainability promise is not inherent to any one AFN but varies considerably within and across AFNs (Michel-Villarreal et al., 2019). Relatively less progress has been made disentangling the structural properties of food systems and how this influences socio-economic outcomes.

Whereas not all AFNs attain the sustainability promise, there are, as suggested by their namesake, ipso facto differences in their structural properties that set them apart from conventional food networks. The alternative in AFN implies some form of innovation in how activities in the food network are organized (Martikainen et al., 2014), many of which relate to logistics or more broadly, supply chain management. Producers in different AFNs choose for example how much time and energy to invest in supply chain management (SCM) activities such as order management, inventory management, warehousing and transportation, marketing, promotion and sales. It is these choices that in aggregate form (part of) the structural properties of specific AFNs and influence socio-economic outcomes.

Even if AFNs are heralded as a way for smaller producers to diversify their income sources and achieve better profit margins (i.e. potential economic outcomes), many are motivated by social factors or outcomes (Bosworth and Willet, 2011; Ilbery and Maye, 2005) such as altruism (Tregear, 2011), cooperation, supporting local economic development, closer geographical and social relations between producers, processors and consumers (Article 2 of Regulation (EU) No 1305/2013 (EU, 2013)), developing sustainable food communities (Berti and Mulligan, 2016) and happiness (Aksoy and Bayram Arli, 2020; Basiago, 1998). Variation in underlying motivations suggests that measuring sustainability (solely) through economic outcomes is problematic (cf. Chouinard et al., 2008). For example, previous AFN research highlights the importance SCM activities have on financial performance (Todorovic et al., 2018; EIP-AGRI Focus Group, European Commission 2015), yet ignores outcome measures related to happiness that can mediate performance or reflect the motivations that matter to individuals. This is an important omission because work-related happiness is an important dimension of sustainability (Aksoy and Bayram Arli, 2020) known to contribute positively to performance, health, lower turnover rates and absenteeism (Archor, 2011; Argyle, 1989; Warr, 2011). Moreover, differences in motivations such as the desire to be happy at work may help to explain differences in the structural properties of AFNs that in turn influence economic outcomes. Finally, extant research tends to aggregate AFNs (Michel-Villarreal et al., 2019) into homogenous groups of actors based on simple heuristics such as where the AFN and customer exchange takes place (e.g. Renting et al., 2003). This increases the risk of conflating results between structural properties and outcomes (Tregear, 2011) and limits our ability to discriminate how SCM differences within and across AFNs contribute to socio-economic outcome measures such as financial performance and happiness. 
Consequently, the objectives in this paper are to: (1) develop a framework for identifying differences in SCM activities at the specific AFN level; and (2) explore how these differences contribute to socio-economic outcomes (i.e. profitability and happiness). Due to the exploratory nature of this study and limited body of quantitative research studying multiple AFNs we also (3) explore differences in the demographic characteristics and attitudes of individuals working in each AFN.

We argue that this exploratory study builds on calls in the literature for disentangling the structural properties of AFNs with their impact on socio-economic outcomes and does so by using a novel supply chain management perspective. In the following sections, we develop a framework for studying and measuring AFN level SCM activities and their relationship with profitability and happiness. This framework is then used on a sample of 286 individuals who self-identified as working in one of five Swedish AFNs.

\section{Frame of reference}

To guide this exploratory study, a set of SCM structural properties and processes needed to understand differences in socio-economic outcomes in AFNs are introduced. These SCM properties and their potential relationship to socio-economic outcomes are summarized in Figure 1.

Lambert (2014: 2) defines SCM as: 'the management of relationships in the network of organizations, from end customers through original suppliers, using key cross-functional business processes to create value for customers and other stakeholders'. A core tenet of SCM therefore, is that organizations compete as members of inter-organizational networks rather than autonomous entities (e.g. Carter et al., 2015). As indicated in our conceptual model (Figure 1), it is important to understand the structure and roles of key supply chain members, and then understand the supply chain processes needed to manage relationships (e.g. Lambert and Enz, 2017). Conceptually, it helps to view supply chains as a structure of network nodes and connecting links, where a node consists of an actor that has the ability to make decisions and maximize its own gain within the parameters in which it operates (Carter et al., 2015). Links represent transactions consisting of the flow of materials, information, and/or financial exchange between nodes.

From the perspective of SCM, AFNs are distinguishable from conventional food supply chains based on their structure and roles played by actors in the network. Typically, but not always, AFNs replace conventional intermediaries. This may create a void that needs to be filled by actors in the AFN and the time and energy needed to do this can be appreciated by understanding the intermediary's main role and the utilities created (such as form, time, place and possession) (e.g. Carter et al., 2015). The gap between production and consumption are bridged by distribution, however the number and type of actors involved (e.g. producers, retailers, wholesalers, logistics service providers, etc.) can vary. The roles and functions performed by intermediaries have been discussed for over a century in the marketing channel literature (e.g. Bucklin, 1960; Clark, 1922; Shaw, 1912; Stern and El-Ansary, 1982) and only slightly evolved over time. There is agreement that certain functions must be performed in the supply chain, but 'who' performs them can be different (Carter et al., 2015). Already Clark (1922) aggregated them into exchange functions (selling and buying), physical distribution functions (ordering, storing and transportation), and facilitating functions (financing, risk taking, standardization and market information). Another important distribution function is to create break bulk and create assortment (Stern and El-Ansary 1982). Alderson (1954) identified the economic rationale for using intermediaries by four different roles: reduction of business ties (leading to a more cost-effective system), scale advantages (e.g. in logistics activities), specialization (increasing competence needed), and risk redistribution (shifting, pooling or hedging). In some AFNs, the individual disintermediates but still needs to be efficient and competitive enough in performing those functions. Todorovic et al. (2018) stresses that the individual must perform many new activities outside the normal core business and mentions logistics activities such as transportation and distribution as the most challenging. For different types of AFNs, the actors involved and their function differs (see the top left corner of Figure 1). 


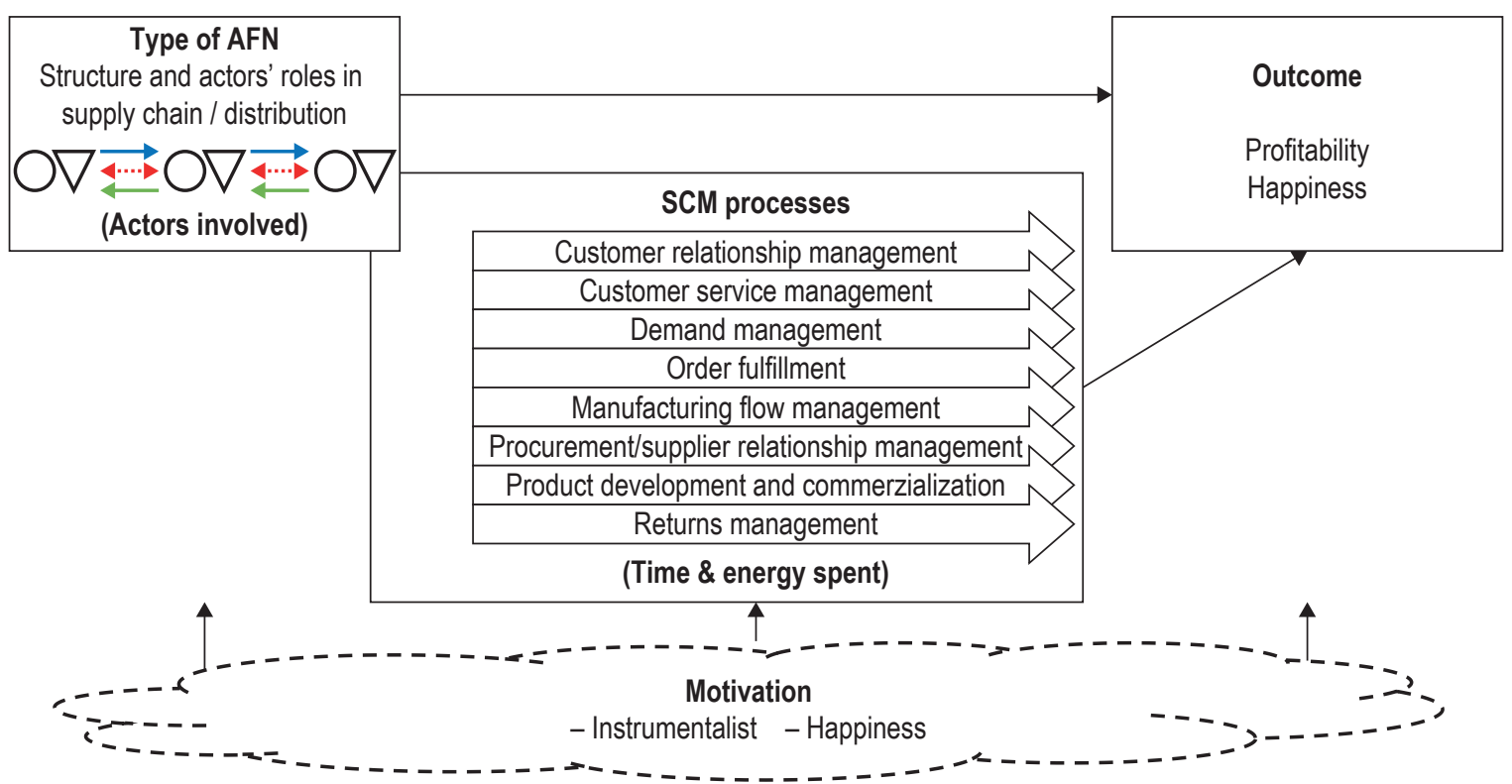

Figure 1. Overriding conceptual framework.

SCM focuses on the three flows of products, information, and money (e.g. Carter et al., 2015), including how different activities and processes are coordinated within and between different partners and resources in the supply chain in order to increase joint profitability. These flows are represented by seven key supply chain processes (Lambert and Cooper, 2000; Lambert and Enz, 2017): 'customer relationship management' (e.g. identifying customer target markets and working with key customers); 'customer service management' (provide customer information about promised shipping dates and product availability); 'demand management' (balancing customer demand and product flow using forecasting, inventory and reducing variability); 'order fulfilment' (provide timely and accurate delivery of orders by integrating manufacturing, distribution and transportation plans); 'manufacturing flow management' (making the products customers want, choosing e.g. between make-to-stock or make-to-order principles); 'procurement/supplier relationship management' (managing relationships with strategic suppliers and partners), and 'product development and commercialization' (identify customer needs and create new products by integrating key customers and suppliers in the process); and 'return management'. It is important to determine what processes need to be implemented with each of the key supply chain members (Lambert and Enz, 2017) and how to successfully achieve cross-actor integration over intercompany silos. The actors performing processes and their activities have to put in enough time and energy to make the supply chain competitive.

Wubben et al. (2013) points out that actors' goals affect their supply chains and how they do business. This has also been recognize by AFN scholars who sometimes divide actors into one of two categories based on their goals (Berti and Mulligan, 2016; Cleveland et al., 2014; Fleischman and Craig, 2015). Instrumentalists are focused on supply chain and market efficiencies, while idealists are primarily connected to social motivations, building sustainable food communities and environmental gains. Fleischman and Craig (2015) describe instrumentalism as the degree to which an organization aims to achieve economic objectives. For many actors within AFNs significant growth is not the foremost objective, but a combination of noneconomic and economic goals (Bosworth and Willett, 2011; Ilbery and Maye, 2005). As the small-scale producers are entrepreneurs, we link this to the discussion on entrepreneurs' happiness (Blanchflower and Oswald, 1992, 2011), and the relationship between happiness and profitability (Gardner and Oswald, 2002). An instrumentalist is probably more happy if being profitable, while an idealist may be happier when social interaction increases (Fleischman and Craig, 2015) and other supply chain activities decrease in terms of time and energy. 
By merging these different perspectives, arrive at a conceptual framework to guide our explorative study (Figure 1) on how different types of AFNs (differentiated by their structure and actors), as well as their SCM processes, contribute to differences in profitability and happiness. Different motivations, and whether they primarily influence choice of AFN, time and energy spent on SCM processes, or perceived outcome will not be measured in this article, but we come back to it in our concluding discussion.

\section{Methods}

\subsection{Participants}

Our purposive (convenience) sample is comprised of participants working in five different types of AFNs: REKO rings, food nodes, farm stores, farmer's markets, and community supported agriculture (CSA). While this approach meant we do not include all the innovative and unique AFNs, we wanted to ensure that our respondents are part of a known network previously referred to as an AFN and engages in similar SCM activities.

The way the AFNs in our sample tend to distribute (through SCM activities) and capture value (through cost and revenue streams) is different (see Table 1 for an overview of these differences). For example, REKOrings share product assortment information via social media while farm stores do this in store or through their websites.

REKO-ring (or simply REKO) is a model for producers to sell local foods directly to consumers. Products are sold based on pre-orders made through closed Facebook rings. The distribution of products to consumers most often occurs via a pre-determined time and meeting place (often a parking lot). (local) food nodes are based on an open-source digital tool where food producers present their food, local consumers order what they like and payments go straight from consumer to producer; deliveries and pick up of food takes place at a predetermined place and time (called node). Community supported agriculture (CSA) has been described as a 'marketing strategy' where consumers are able to purchase shares in a farm before planting and receive a share in the harvest (Brown and Miller, 2008). Farm stores in the context of this study refer to familyowned stores most often located adjacent to a farm that sell a range of fresh fruits, eggs, vegetables, dried goods, honey, and other agricultural products.

The main SCM characteristics of each type of AFN are summarized in Table 1: the 'information flow' handling regarding assortment and order taking; the 'material flow' such as who defines the assortment (normally managed by intermediaries in retail), delivery lead times, production logic, delivery points, and transportation; and 'money flow' such as payment (revenue stream).

Participants in each AFN were identified using a variety of methods. For the REKO group we emailed Facebook administrators in charge of Swedish rings and asked for permission to solicit participation on their wall. The rest were identified through internet searches where we combined secondary information (i.e. known actors in these AFNs) with actors having a web presence that we discovered. Because each of the five AFNs are 'branded' (in Swedish), it was relatively easy to distinguish between actors as they referred to their AFN activities by name (e.g. REKO, CSA).

\subsection{Materials and procedure}

579 actors working in (at least) one of the five AFNs who also had an email address were identified and invited to take part in an online survey. The survey contained 157 questions and took an average (based on pilot testing) of 20 minutes to complete. All participants were offered a free movie ticket for taking part in the survey. In total, we received 286 responses for an overall response rate of $49 \%$. 
Table 1. Supply chain management characteristics of different types of alternative food networks studied.

\begin{tabular}{|c|c|c|c|c|c|}
\hline & REKO-rings & Local food nodes & Farm stores & Farmers market & $\begin{array}{l}\text { Community } \\
\text { supported } \\
\text { agriculture }\end{array}$ \\
\hline $\begin{array}{l}\text { Showing } \\
\text { assortment } \\
\text { information }\end{array}$ & $\begin{array}{l}\text { On virtual platform using } \\
\text { social media (often } \\
\text { Facebook), could link to } \\
\text { producer's website }\end{array}$ & $\begin{array}{l}\text { On virtual open platform } \\
\text { using local food nodes } \\
\text { homepage. }\end{array}$ & $\begin{array}{l}\text { In farm shop } \\
\text { (and potentially } \\
\text { website) }\end{array}$ & $\begin{array}{l}\text { At market (and } \\
\text { sometimes on } \\
\text { homepage). } \\
\text { Central webpage } \\
\text { connects to } \\
\text { producers' } \\
\text { websites or social } \\
\text { media (Facebook) }\end{array}$ & $\begin{array}{l}\text { Broad assortment } \\
\text { informed before } \\
\text { signing contract. } \\
\text { Final assortment } \\
\text { defined by } \\
\text { harvest. }\end{array}$ \\
\hline Order taking & $\begin{array}{l}\text { Direct producer via } \\
\text { Facebook, e-mail, etc. }\end{array}$ & $\begin{array}{l}\text { On the platform } \\
\text { (localfoodnodes.org). } \\
\text { Confirmation by e-mail. }\end{array}$ & In farm shop & At market & $\begin{array}{l}\text { Subscription } \\
\text { before season. }\end{array}$ \\
\hline Assortment & $\begin{array}{l}\text { Customer orders from } \\
\text { producers defined } \\
\text { assortment }\end{array}$ & $\begin{array}{l}\text { Customer orders from } \\
\text { producers defined } \\
\text { assortment }\end{array}$ & $\begin{array}{l}\text { Customers choses } \\
\text { from products } \\
\text { displayed in store }\end{array}$ & $\begin{array}{l}\text { Customers choses } \\
\text { from products } \\
\text { displayed at } \\
\text { market }\end{array}$ & $\begin{array}{l}\text { Is defined by the } \\
\text { harvest. }\end{array}$ \\
\hline Delivery time & $\begin{array}{l}\text { Yes. Pre-defined joint } \\
\text { events by REKO- } \\
\text { administrator, } \\
\text { e.g. weekly }\end{array}$ & $\begin{array}{l}\text { Yes. Pick-up time defined } \\
\text { on order receipt by } \\
\text { producer }\end{array}$ & $\begin{array}{l}\text { None, direct in } \\
\text { shop. }\end{array}$ & $\begin{array}{l}\text { None, direct at } \\
\text { market. (Markets } \\
\text { on predefined } \\
\text { dates announced at } \\
\text { central webpage) }\end{array}$ & $\begin{array}{l}\text { When harvested, } \\
\text { could be spread } \\
\text { out in intervals. }\end{array}$ \\
\hline $\begin{array}{l}\text { Production } \\
\text { logic }\end{array}$ & $\begin{array}{l}\text { Often make-to-order, can } \\
\text { be make-to-stock }\end{array}$ & $\begin{array}{l}\text { Often make-to-order, can } \\
\text { be make-to-stock }\end{array}$ & Make-to-stock & Make-to-stock & $\begin{array}{l}\text { Ships/sells what } \\
\text { harvested. }\end{array}$ \\
\hline Delivery point & $\begin{array}{l}\text { Pre-defined joint locations } \\
\text { by REKO-administrator, } \\
\text { few per city }\end{array}$ & $\begin{array}{l}\text { Pick-up place informed on } \\
\text { order receipt by producer, } \\
\text { linked to chosen node }\end{array}$ & Farm shop & Market & $\begin{array}{l}\text { Normally home } \\
\text { delivery (or } \\
\text { defined pick-up } \\
\text { point) }\end{array}$ \\
\hline $\begin{array}{l}\text { Responsible } \\
\text { for goods } \\
\text { transportation }\end{array}$ & $\begin{array}{l}\text { Producer to defined } \\
\text { location, customer brings } \\
\text { home }\end{array}$ & $\begin{array}{l}\text { Producer to defined } \\
\text { location, customer brings } \\
\text { home }\end{array}$ & $\begin{array}{l}\text { Customer brings } \\
\text { home products. } \\
\text { (if web shop, } \\
\text { producer) }\end{array}$ & $\begin{array}{l}\text { Producer to market, } \\
\text { customer brings } \\
\text { home }\end{array}$ & Normally producer \\
\hline Payment & $\begin{array}{l}\text { Advance payment before } \\
\text { meeting, direct between } \\
\text { producer and customer }\end{array}$ & $\begin{array}{l}\text { Flexible payment } \\
\text { (advance, at deliver or } \\
\text { by invoice), decided by } \\
\text { producer and customer }\end{array}$ & $\begin{array}{l}\text { Direct payment in } \\
\text { farm shop. }\end{array}$ & $\begin{array}{l}\text { Direct payment at } \\
\text { market. }\end{array}$ & $\begin{array}{l}\text { Subscription, paid } \\
\text { before meaning } \\
\text { customer takes } \\
\text { higher risk. }\end{array}$ \\
\hline $\begin{array}{l}\text { Intermediary } \\
\text { role }\end{array}$ & $\begin{array}{l}\text { Setting up virtual food } \\
\text { platform on social } \\
\text { media, defining rules and } \\
\text { guidelines, controlling } \\
\text { membership, defining } \\
\text { delivery joint time and } \\
\text { location. Both producers } \\
\text { and customers should be } \\
\text { members. }\end{array}$ & $\begin{array}{l}\text { Setting up open online } \\
\text { platform, defining rules, } \\
\text { controlling membership, } \\
\text { getting in co-funding and } \\
\text { co-creation to develop } \\
\text { the platform. Producers } \\
\text { should be members, } \\
\text { customers are requested } \\
\text { to be. }\end{array}$ & $\begin{array}{l}\text { None - direct } \\
\text { channel. }\end{array}$ & $\begin{array}{l}\text { Arranges the } \\
\text { markets and } \\
\text { define roles and } \\
\text { responsibilities. } \\
\text { Producers should } \\
\text { be members. }\end{array}$ & $\begin{array}{l}\text { None - direct } \\
\text { channel. }\end{array}$ \\
\hline
\end{tabular}


Our survey was administrated online using survey software provided by Netigate (https://www.netigate.net/). Upon starting the survey, each person was required to read how their data (and any personal information) would be used, how they could get more information about the project, and that they had a right to withdraw their data responses from being used. In order to proceed with the survey, they were required to provide digitally signed consent. All participants received the same questions in the survey, however we adjusted questions that included the name of the AFN. For example, one control question asked: I am involved in REKO (as a producer, processor, other) and measured this as yes/no. For other groups receiving the same question 'REKO' was replaced with food node or CSA, or farmers market, or farm store. We cross referenced all of the 579 participants identified and ensured that none of them received more than one survey in the event they were involved in more than one AFN.

Due to the exploratory nature of our study, we included a wide range of variables in our survey and not all of them were intended to be used in this research. For example, we had a battery of questions related to how actors communicated value inspired by Chen (2013) and detailed questions related to cooperation inspired by Carbone et al. (2015). Consequently, we only present the variables that were used in this article. Our two dependent variables (DVs) were profitability and happiness. We measured profitability as a subjective assessment of profitability within a specific AFN using 4 Likert type questions measured on 5-point scales. We later combined these questions to create a 'profitability scale' using the statistical mean of all four question and checked their reliability using Cronbach's alpha (alpha=0.751). Subjective performance rather than actual performance was chosen due to our belief that actors in the AFNs would find it difficult to decouple profits in a specific chain from their overall reporting. Also, previous research has found strong correlations between subjective assessments and objective measures (e.g. Slater and Narver, 1994). We operationalized happiness as a domain-specific construct that is related to occupational experience (Warr, 2011). A scale for happiness was created by combining the statistical mean of four Likert type questions assessed with 5-point measurements (strongly disagree - strongly agree). These items measured enjoyment, fun, happiness, and liking the work done in a specific AFN (alpha=0.892).

We captured a number of items intended for use as independent variables (IVs). The main IVs measured to help us understand differences in profitability were based on 19 single item measures representing time and energy spent on SCM processes and operationalized using Lambert and Enz's (2017) model. As we explain in the next section, we did not reduce these items further. To predict happiness, we measured a number of items relating to 'fair wages', 'future beliefs', things that 'reduce logistics effort' and 'simplify customer service' as well as 'cooperation'. these items were combined using the statistical mean to create reliable scales (all of which demonstrated good reliability with a Cronbach alpha of $>0.70$ ). A full description of our items and scales, including their reliability, means, and standard deviations is located in the Supplementary material.

\section{Results and analysis}

\subsection{Descriptive statistics of sample participants sorted by alternative food networks}

Table 2 summarizes the descriptive statistics of the sample population sorted by 'branded' AFN and includes age, gender, their primary business, percentage of total sales and profits from the AFN.

In total, we received responses from 286 participants across the AFNs ranging from a low of 34 in CSA to a high of 93 responses in the AFN channel farmer's market. The average age of respondents ranged from 42 in CSA to 57 for farmer market. Women represented 67, 60, 74, 57 and $42 \%$ of the sample in REKO, food node, farm store, farmers market and CSA respectively. Respondents in all channels indicated their primary business was related to food production, however there was some indication of pluriactivity across channels. For example, 7 of the 57 respondents in food node indicated their main business was related to processing. Respondents in the farm store group were the most pluriactive, with 9 indicating their primary business was related to processing, 1 was an intermediary, 14 mentioned farm store, 4 reported not agriculture and 1 reported other. 
Table 2. Descriptive statistics of sample participants sorted by alternative food networks. ${ }^{1,2}$

\begin{tabular}{|c|c|c|c|c|c|c|c|c|c|c|c|c|}
\hline \multirow[t]{2}{*}{ Variable } & \multicolumn{4}{|c|}{$\operatorname{REKO}\left(n=41^{b}\right)$} & \multicolumn{4}{|c|}{ Food node $\left(n=57^{b}\right)$} & \multicolumn{4}{|c|}{ Farm store $\left(n=61^{b}\right)$} \\
\hline & Mean $^{\mathbf{a}}$ & St.dev & Min & Max & Mean $^{a}$ & St.dev & Min & Max & Mean $^{\mathrm{a}}$ & St.dev & Min & Max \\
\hline Age & 44 & 10.63 & 18 & 62 & 46 & 12.08 & 26 & 72 & 52 & 11.40 & 25 & 75 \\
\hline Gender (\% women & $67 \%$ & - & - & - & $60 \%$ & - & - & - & $74 \%$ & - & - & - \\
\hline \multicolumn{13}{|l|}{ Primary business (frequencies) } \\
\hline Producer & 28 & - & - & - & 37 & - & - & - & 30 & - & - & - \\
\hline Processor & 2 & - & - & - & 7 & - & - & - & 9 & - & - & - \\
\hline Intermediary & 0 & - & - & - & 1 & - & - & - & 1 & - & - & - \\
\hline Farmstore & 0 & - & - & - & 0 & - & - & - & 14 & - & - & - \\
\hline Not agriculture & 2 & - & - & - & 3 & - & - & - & 4 & - & - & - \\
\hline Other & 6 & - & - & - & 4 & - & - & - & 1 & - & - & - \\
\hline AFN percentage of total sales & $30 \%$ & 28.30 & 1 & 90 & $22 \%$ & 25.19 & 0 & 80 & $43 \%$ & 29.62 & 1 & 90 \\
\hline AFN percentage of total profit & $25 \%$ & 26.49 & 0 & 90 & $19 \%$ & 26.22 & 0 & 100 & $41 \%$ & 30.92 & 0 & 90 \\
\hline Years working in channel & $1-2$ years & - & - & - & $1-2$ years & - & - & - & $5-6$ years & - & - & - \\
\hline Importance of channel to business & 4.00 & 1.16 & 1 & 5 & 3.16 & 1.27 & 1 & 5 & 4.00 & 0.98 & 2 & 5 \\
\hline Hourly wage in SEK & 94 & 66.92 & 0 & 300 & 85 & 89.76 & 0 & 300 & 93 & 78.92 & 0 & 250 \\
\hline \multirow[t]{2}{*}{ Variable } & \multicolumn{4}{|c|}{ Farmers market $\left(n=93^{b}\right)$} & & & & & \multicolumn{4}{|c|}{$\operatorname{CSA}\left(n=34^{b}\right)$} \\
\hline & $\operatorname{Mean}^{\mathrm{a}}$ & St.dev & Min & Max & & & & & Mean $^{a}$ & St.dev & Min & $\operatorname{Max}$ \\
\hline Age & 57 & 11.39 & 28 & 75 & & & & & 42 & 12.08 & 24 & 69 \\
\hline Gender $(\%$ women & $60 \%$ & - & - & - & & & & & $44 \%$ & - & - & - \\
\hline \multicolumn{13}{|l|}{ Primary business (frequencies) } \\
\hline Producer & 66 & - & - & - & & & & & 32 & - & - & - \\
\hline Processor & 12 & - & - & - & & & & & 0 & - & - & - \\
\hline Intermediary & 1 & - & - & - & & & & & 0 & - & - & - \\
\hline Farmstore & 5 & - & - & - & & & & & 0 & - & - & - \\
\hline Not agriculture & 1 & - & - & - & & & & & 2 & - & - & - \\
\hline Other & 2 & - & - & - & & & & & 0 & - & - & - \\
\hline AFN percentage of total sales & $27 \%$ & 23.33 & 0 & 90 & & & & & $50 \%$ & 34.00 & 3 & 100 \\
\hline AFN percentage of total profit & $25 \%$ & 23.20 & 0 & 81 & & & & & $43 \%$ & 37.24 & 0 & 100 \\
\hline Years working in channel & $>10$ years & - & - & - & & & & & $1-2$ years & - & - & - \\
\hline Importance of channel to business & 4.13 & 0.96 & 1 & 5 & & & & & 4.19 & 0.98 & 2 & 5 \\
\hline Hourly wage in SEK & 238 & 110.45 & 0 & 500 & & & & & 197 & 75.63 & 100 & 450 \\
\hline
\end{tabular}

As a percentage of total sales, responses ranged in average across AFNs in average from a low of $22 \%$ in food node to a high of 50\% in CSA. Similarly, the percentage of total profits estimated by participants in each channel ranged from a low of $19 \%$ in food node to a high of $43 \%$ in CSA. There was considerable deviation across these responses with a minimum AFN percentage of total profits estimated by participants to range from 0 to $100 \%$.

On average, respondents in the farmer market group indicated working in the channel for more than 10 years. The next most time on average working in a channel was reported by those in farm stores (between 5-6 years), followed by REKO, food node, and CSA who all reported working in the channel for 1 to 2 years on average. The importance of working in each channel to the overall business was above the mean for all groups ranging from 3.16 in food node to 4.19 in CSA on a 5 point Likert scale (strongly disagree=1 to strongly agree $=5$ ). 
Finally, an estimated hourly wage was reported for participants in each AFN. The lowest reported hourly wages was from the food node group at 85 sek (circa \$ 8.50 USD at time of survey) and up to a high of 238 sek (circa $\$ 23.80$. The range and standard deviations of wages, percentage of sales, etc. can be found in Table 2.

\subsection{Time and energy spend on supply chain management activities in different alternative food networks}

To understand channel differences in terms of the time and energy spent on SCM activities, we conducted a Welch ANOVA as it does not make assumptions about equal group sizes or homogeneity of variances (Welch, 1951).

Using the 19, single item measures related to time and energy spent as our dependent variable and AFN channel as our fixed factor reveals a significant value $(P>0.05)$ for the items V15, V18, V20, V22, V24, V26, V29, and V30 (Table 3 for coding). All other variables showed a significant result $(P<0.05)$ on the Welch test and were followed up with a post-hoc comparison using the Games-Howell test which does not assume equal variances and sample sizes.

Table 3 provides the mean values for each variable explored and the mean totals across variables and type of AFN. We see from the mean totals that the activity taking the least amount of time is managing returns (mean=1.71) followed by working with transportation (mean=2.08) and producing to order based on customer demand (mean=2.53).

In contrast, the activity AFN participants reported spending the most time and energy on was ensuring customers are satisfied (mean=4.03), followed by communicating with customers (mean=3.70). Based solely on mean totals across groups, AFN actors spend the least amount of time and energy on SCM activities and the most amount working with marketing activities. When examining the time and energy spent between channels, those working with CSA indicated spending the least amount of time and energy on the range of activities we measured (mean=2.79) while those working in farm stores spent the most (mean=3.18).

Table 3 also highlights significant mean differences between the types of AFNs (indicated in parentheses). For example, in the first row, first column, we see that there is a statistically significant difference between how much time and energy is spent managing customer relations between REKO (A) and food node (B) - this difference is significant at the $P<0.05$ level as denoted by one asterisk (*). Similarly, for the same activity (first row, second column) we see that food nodes (B) spend significantly less time and energy (mean 2.62) than farm stores (C) (mean 3.71) and farmer's markets (D) (mean 3.25). Overall, there are 28 instances of significant paired differences between 'time and energy spent' on various supply chain management activities and channel. This indicates clear differences between how different AFNs organize their business model. In the next section we explore the relationship between these activities and profitability.

\subsection{Correlations between time and energy spent on supply chain management activities and profitability}

Our initial intention was to create a reduced number of scales for the 19 items that measured SCM activities for use in parametric tests. However, a principal component analysis (PCA), revealed that many of the items were either unidimensional, loaded on unexpected factors, or exhibited side-loadings of substantial magnitude. Consequently, a Spearman rank-order correlation was used to test for the strength and direction of the relationship between our 19 IVs and profitability. We did this in two ways: first we looked at the bi-variate correlations and second, we explored partial correlations when controlling for age, gender, and percentage of sales attributed to the AFN. The results of this analysis are summarized in Table 4.

Looking across AFNs, only the variable 'matching supply with demand' correlated significantly (and positively) with all groups; this correlation was strongest in the REKO ring group (partial rho=0.057) and weakest (but still significant at $P<0.10$ ) in the farmer's market group (partial rho=0.016). 'Understand and develop new products customers want' was significant across four of the five groups with food nodes being 
the sole exception. Similarly, 'using information technology to gain competitive advantage' was correlated with profitability in three of the five groups (not significant for food nodes or farmers markets).

Table 3. Welch ANOVA and Games-Howell Post-hoc test of time and energy spent on supply chain management activities (later used to regress profit). ${ }^{1}$

\begin{tabular}{|c|c|c|c|c|c|c|c|}
\hline & & $\mathbf{R E K O}=\mathbf{A}$ & Food node $=$ B & $\begin{array}{l}\text { Farm } \\
\text { store }=\mathrm{C}\end{array}$ & $\begin{array}{l}\text { Farmer } \\
\text { market }=\text { D }\end{array}$ & $\begin{array}{l}\text { CSA } \\
=\mathbf{E}\end{array}$ & $\begin{array}{l}\text { Mean } \\
\text { totals }\end{array}$ \\
\hline \multicolumn{8}{|c|}{$\begin{array}{l}\text { If I just think about the customers and } \\
\text { products related to this channel, I would say } \\
\text { that we spend a lot of time and energy: }\end{array}$} \\
\hline V28 & $\begin{array}{l}\text { Manage returns (e.g. replace spoiled } \\
\text { food, wrong orders) }\end{array}$ & 1.78 & 1.60 & 1.59 & $2.00\left(\mathrm{DE}^{*}\right)$ & 1.32 & 1.71 \\
\hline V25 & $\begin{array}{l}\text { Work with transportation companies/ } \\
\text { partners to deliver goods as needed }\end{array}$ & $2.19(\mathrm{AE})$ & 1.91 & $\begin{array}{l}2.41 \\
\left(\mathrm{CE}^{* *}\right)\end{array}$ & $2.12\left(\mathrm{DE}^{*}\right)$ & 1.45 & 2.08 \\
\hline V24 & $\begin{array}{l}\text { Produce to order and deliver on } \\
\text { customer demand }\end{array}$ & 2.78 & 2.56 & 2.64 & 2.52 & 2.03 & 2.53 \\
\hline V20 & $\begin{array}{l}\text { Solve transportation of goods to } \\
\text { customers }\end{array}$ & 2.94 & 3.02 & 2.62 & 2.42 & 3.10 & 2.74 \\
\hline V19 & $\begin{array}{l}\text { Accept orders from customers before } \\
\text { delivery }\end{array}$ & $\begin{array}{l}3.64\left(\mathrm{AC}^{*}\right) \\
\left(\mathrm{AD}^{* * *}\right)\left(\mathrm{AE}^{* * *}\right)\end{array}$ & $3.02\left(\mathrm{BE}^{*}\right)$ & $2.83(\mathrm{CE})$ & 2.41 & 2.03 & 2.75 \\
\hline V18 & Meet customer lead times & 2.75 & 2.70 & 2.88 & 2.89 & 2.42 & 2.77 \\
\hline V26 & $\begin{array}{l}\text { Understand and develop new } \\
\text { products customers want }\end{array}$ & 3.06 & 2.60 & 2.97 & 2.96 & 2.39 & 2.84 \\
\hline V23 & $\begin{array}{l}\text { Maintain supply to match customers } \\
\text { lead time demands }\end{array}$ & $2.61\left(\mathrm{AC}^{*}\right)$ & $2.78(\mathrm{BC})$ & $3.47(\mathrm{CE})$ & 2.97 & 2.58 & 2.95 \\
\hline $\mathrm{V} 30$ & $\begin{array}{l}\text { Using information technology needed } \\
\text { to compete in this channel }\end{array}$ & 3.08 & 2.98 & 3.24 & 2.88 & 2.71 & 2.99 \\
\hline V13 & Understand customer demand & 3.00 & $2.57\left(\mathrm{BC}^{* *} \mathrm{BD}^{* *}\right)$ & 3.36 & 3.33 & 3.00 & 3.11 \\
\hline V21 & $\begin{array}{l}\text { Ensure a stable flow of products } \\
\text { available for customers }\end{array}$ & 3.28 & 2.84 & 3.34 & $2.84\left(\mathrm{DE}^{*}\right)$ & 3.61 & 3.12 \\
\hline V17 & $\begin{array}{l}\text { Understand what/when customer } \\
\text { buys so it is available }\end{array}$ & $3.39(\mathrm{AE})$ & 2.93 & $\begin{array}{l}3.36 \\
\left(\mathrm{CE}^{*}\right)\end{array}$ & $3.38\left(\mathrm{DE}^{*}\right)$ & 2.52 & 3.19 \\
\hline V12 & Managing customer relations & $3.36\left(\mathrm{AB}^{*}\right)$ & $2.61(\mathrm{BC} * * * \mathrm{BD})$ & 3.71 & 3.25 & 3.28 & 3.26 \\
\hline V15 & $\begin{array}{l}\text { Informing customers about delivery/ } \\
\text { lead time }\end{array}$ & 3.39 & 3.28 & 3.26 & 3.11 & 3.50 & 3.26 \\
\hline V29 & $\begin{array}{l}\text { Ensure machines and facilities } \\
\text { needed are in working order }\end{array}$ & 3.17 & 3.02 & 3.24 & 3.52 & 3.23 & 3.27 \\
\hline V16 & Matching offering and demand & 3.42 & $2.83\left(\mathrm{BD}^{*}\right)$ & 3.34 & $3.58(\mathrm{DE})$ & 2.87 & 3.28 \\
\hline $\mathrm{V} 22$ & $\begin{array}{l}\text { Process products before selling (e.g. } \\
\text { washing, packaging) }\end{array}$ & 3.61 & 3.51 & 3.67 & 3.66 & 3.74 & 3.64 \\
\hline V27 & $\begin{array}{l}\text { Communicate/explain and/or sell } \\
\text { products to customers }\end{array}$ & 3.61 & $\begin{array}{l}3.00\left(\mathrm{BC}^{* * *}\right) \\
\left(\mathrm{BD}^{* * *}\right)\end{array}$ & $\begin{array}{l}4.16 \\
\left(\mathrm{CE}^{* *}\right)\end{array}$ & $4.00\left(\mathrm{DE}^{*}\right)$ & 3.23 & 3.70 \\
\hline \multirow[t]{2}{*}{ V14 } & Ensure customers are satisfied & 3.92 & $3.61\left(\mathrm{BC}^{* *}\right)$ & 4.36 & 4.07 & 4.03 & 4.03 \\
\hline & Mean totals: & 3.10 & 2.81 & 3.18 & 3.07 & 2.79 & 3.02 \\
\hline
\end{tabular}

${ }^{1}$ Mean values for questions and channel. Letters in parentheses denote a significant mean difference between two channels based on Games-Howell post hoc test where: not having asterisk $P<0.10 ; * P<0.05 ; * * P<0.01 ; * * * P<0.001$. CSA $=$ community supported agriculture. 
Table 4. Spearman's rho test of bi-variate correlations between time and energy spent on alternative food networks supply chain management activities and profitability (including partial correlations controlling for percentage of sales generated in type pf alternative food network). ${ }^{1}$

\begin{tabular}{|c|c|c|c|c|c|c|c|c|c|c|}
\hline \multirow[t]{2}{*}{ Variable } & \multicolumn{2}{|c|}{$\operatorname{REKO}(d f=31)$} & \multicolumn{2}{|c|}{$\begin{array}{l}\text { Food node } \\
(\mathrm{df}=37)\end{array}$} & \multicolumn{2}{|c|}{$\begin{array}{l}\text { Farm store } \\
(d f=51)\end{array}$} & \multicolumn{2}{|c|}{$\begin{array}{l}\text { Farmers market } \\
(\mathrm{df}=64)\end{array}$} & \multicolumn{2}{|c|}{$\operatorname{CSA}(d f=27)$} \\
\hline & rho & $\begin{array}{l}\text { part. } \\
\text { rho }\end{array}$ & rho & $\begin{array}{l}\text { part. } \\
\text { rho }\end{array}$ & rho & $\begin{array}{l}\text { part. } \\
\text { rho }\end{array}$ & rho & $\begin{array}{l}\text { part. } \\
\text { rho }\end{array}$ & rho & $\begin{array}{l}\text { part. } \\
\text { rho }\end{array}$ \\
\hline Managing customer relations & 0.05 & 0.02 & 0.19 & 0.02 & 0.02 & 0.02 & 0.13 & 0.11 & 0.18 & 0.20 \\
\hline Understand customer demand & 0.16 & 0.20 & $0.26 *$ & 0.07 & $0.35 * * *$ & $0.35 * * *$ & 0.08 & 0.06 & 0.18 & 0.18 \\
\hline Ensure customers are satisfied & 0.13 & 0.05 & 0.08 & -0.05 & $0.25 *$ & $0.25 *$ & 0.11 & 0.10 & 0.14 & 0.12 \\
\hline $\begin{array}{l}\text { Informing customers about delivery/ } \\
\text { lead time }\end{array}$ & 0.16 & 0.19 & 0.12 & 0.00 & 0.19 & 0.19 & -0.02 & -0.04 & $0.40^{*}$ & $0.38^{*}$ \\
\hline Matching offering and demand & $0.55 * * *$ & $0.57 * * *$ & $0.38 * *$ & 0.22 & $0.24 *$ & $0.24 *$ & 0.19 & 0.16 & 0.28 & 0.28 \\
\hline $\begin{array}{l}\text { Understand what/when customer buys so } \\
\text { it is available }\end{array}$ & $0.32 *$ & 0.26 & $0.50 * * *$ & $0.37 * *$ & 0.15 & 0.15 & 0.07 & 0.05 & -0.04 & -0.02 \\
\hline Meet customer lead times & 0.21 & 0.18 & 0.17 & 0.17 & 0.19 & 0.19 & 0.03 & 0.01 & 0.15 & 0.14 \\
\hline $\begin{array}{l}\text { Accept orders from customers before } \\
\text { delivery }\end{array}$ & -0.09 & -0.10 & $0.34 *$ & 0.24 & 0.15 & 0.15 & -0.03 & -0.06 & 0.02 & 0.08 \\
\hline $\begin{array}{l}\text { Solve transportation of goods to } \\
\text { customers }\end{array}$ & 0.07 & 0.05 & 0.10 & 0.07 & 0.18 & 0.18 & 0.07 & 0.05 & $0.31 *$ & 0.30 \\
\hline $\begin{array}{l}\text { Ensure a stable flow of products } \\
\text { available for customers }\end{array}$ & $0.39 * *$ & $0.30^{*}$ & 0.12 & 0.13 & $0.41^{* *}$ & $0.41 * *$ & 0.04 & 0.08 & 0.20 & 0.14 \\
\hline $\begin{array}{l}\text { Process products before selling (e.g. } \\
\text { washing. packaging) }\end{array}$ & 0.12 & 0.06 & 0.00 & -0.06 & 0.12 & 0.12 & 0.06 & 0.07 & 0.11 & 0.11 \\
\hline $\begin{array}{l}\text { Maintain supply to match customers lead } \\
\text { time demands }\end{array}$ & -0.06 & -0.11 & -0.07 & -0.10 & $0.23 *$ & $0.23 *$ & 0.11 & 0.10 & $0.38^{*}$ & $0.38 *$ \\
\hline $\begin{array}{l}\text { Produce to order and deliver on customer } \\
\text { demand }\end{array}$ & 0.03 & 0.05 & $0.32 \%$ & 0.23 & 0.12 & 0.12 & -0.01 & -0.02 & -0.05 & -0.05 \\
\hline $\begin{array}{l}\text { Work with transportation companies/ } \\
\text { partners to deliver goods as needed }\end{array}$ & 0.06 & 0.13 & -0.03 & -0.03 & $0.32 * *$ & $0.32 * *$ & 0.11 & 0.16 & 0.08 & 0.08 \\
\hline $\begin{array}{l}\text { Understand and develop new products } \\
\text { customers want\# }\end{array}$ & $0.42 * *$ & $0.44 * *$ & -0.11 & -0.23 & $0.27 *$ & $0.27^{*}$ & 0.16 & 0.14 & $0.48^{* * * *}$ & $0.50^{* * * *}$ \\
\hline $\begin{array}{l}\text { Communicate/explain and/or sell } \\
\text { products to customers }\end{array}$ & 0.27 & 0.26 & 0.21 & 0.15 & 0.11 & 0.11 & 0.14 & 0.11 & 0.06 & 0.09 \\
\hline $\begin{array}{l}\text { Manage returns (e.g. replace spoiled } \\
\text { food. wrong orders) }\end{array}$ & 0.02 & 0.08 & -0.02 & -0.13 & 0.09 & 0.09 & 0.13 & 0.12 & 0.21 & 0.24 \\
\hline $\begin{array}{l}\text { Ensure machines and facilities needed } \\
\text { are in working order }\end{array}$ & 0.19 & 0.19 & 0.00 & 0.00 & -0.04 & -0.04 & 0.12 & 0.12 & 0.25 & 0.33 \\
\hline $\begin{array}{l}\text { Getting relevant information needed to } \\
\text { compete in this channel }\end{array}$ & $0.37 *$ & $0.49 * * *$ & 0.03 & -0.09 & $0.36 * * *$ & $0.36^{* * * *}$ & 0.12 & 0.09 & $0.35 *$ & $0.39 *$ \\
\hline Percentage_sales_dummy & $0.32 *$ & & $0.51 * * *$ & & 0.00 & & $0.27 * *$ & & 0.17 & \\
\hline
\end{tabular}

${ }^{1}$ Significant correlation based on one-tailked tests and Spearman's rho. rho=bivariate correlation; part rho=partial correlation controlling for percentage sales. Bold and italicized correlations indicate a significant relation where: not having asterisk $P<0.10$; $* P<0.05 ; * * P<0.01 ; * * * P<0.001$. CSA $=$ community supported agriculture. 
Three of the 19 SCM activities showed no correlation with profitability in any groups including: 'managing returns', and surprisingly 'process products before selling', and 'managing customer relations'. Across all groups, participants indicated spending the third most amount of time and energy on processing products before selling (mean=3.64) and were well above the mean total of 3.02 in regard to managing customer relations $($ mean $=3.26)$.

Five activities ('ensure customers are satisfied', 'meet customer lead times', 'accept orders from customers before delivery', 'produce to order and deliver on demand', 'work with transportation companies to deliver products'), are uniquely correlated to profitability in only one channel.

Finally, only minor differences between the bi-variate and partial correlation models presented in Table 4 were found. For example, the correlation between 'understanding consumer demand' and profitability was significant in the Food Node group based on the bi-variate correlation rho. However, when controlling for the percentage of overall sales made in channel (i.e. when more than $15 \%$ of total sales come from this channel) understanding consumer demand loses its significance. We take from this that although percentage of sales was significantly correlated with profitability in 3 of the 5 groups, it mostly captures unexplained variance.

\subsection{Differences in happiness and its antecedents across alternative food networks}

Table 5 reports the results of a one-way ANOVA with 'happiness', 'fair wages', 'profitability', 'future beliefs', 'reduces logistics effort', 'simplifies customer service' and 'cooperating with marketing' as our DVs and AFN channel as our fixed factor.

We find that the 'happiest' people are part of the CSA group. With a mean of 4.48, they report being significantly more happy than the next happiest group, REKO, (at $P<0.10)$ as well as all other groups. This is impressive because all of the groups in our sample tend to report being happy (the lowest mean score for happiness is 3.52/5 for the food node group). It is also surprising because they are not the most profitable (most profitable $=$ farmer's market group), nor do they believe that they receive the fairest wages. However, the CSA group feels the most optimistic about their future (mean=3.98) and believes that they save the most amount of time among all groups working with logistics and customer service.

Conversely, the least content group might be those working in food nodes. They are somewhere in the middle when it comes to receiving fair wages (mean=2.51) and they do not differ significantly from any

Table 5. Games-Howell post hoc comparison of scale means (later used to regress happiness) sorted by channel. ${ }^{1}$

\begin{tabular}{|c|c|c|c|c|c|}
\hline & Alternative food netwo & & & & \\
\hline Scale & $\mathbf{R E K O}=\mathbf{A}$ & Food node $=B$ & Farm store $=\mathrm{C}$ & $\begin{array}{l}\text { Farmer } \\
\text { market }=\text { D }\end{array}$ & $\mathbf{C S A}=\mathbf{E}$ \\
\hline Happiness & $3.93(\mathrm{AE})$ & $3.52\left(\mathrm{BE}^{* * *}\right)$ & $3.90\left(\mathrm{CE}^{* *}\right)$ & $3.88\left(\mathrm{DE}^{* * *}\right)$ & 4.48 \\
\hline Fair wages & $2.23(\mathrm{AD})$ & 2.51 & $2.24(\mathrm{CD})$ & 2.81 & 2.53 \\
\hline Profitable & 3.20 & $2.88\left(\mathrm{BD}^{*}\right)$ & $2.88\left(\mathrm{CD}^{*}\right)$ & 3.45 & 3.16 \\
\hline Future beliefs & $3.69(\mathrm{AD})$ & $3.32\left(\mathrm{BE}^{*}\right)$ & $3.21\left(\mathrm{CE}^{* *}\right)$ & $3.16\left(\mathrm{DE}^{* * *}\right)$ & 3.98 \\
\hline Reduces logistics effort & $2.91\left(\mathrm{AE}^{*}\right)$ & $2.65\left(\mathrm{BE}^{* * *}\right)$ & $3.15(\mathrm{CD})$ & $2.45\left(\mathrm{DE}^{* * *}\right)$ & 3.72 \\
\hline Simplify customer service & 3.38 & $2.96\left(\mathrm{BE}^{*}\right)$ & $3.51(\mathrm{CD})$ & $2.97\left(\mathrm{DE}^{*}\right)$ & 3.75 \\
\hline Cooperate with marketing & $3.24\left(\mathrm{AC}^{* *} \mathrm{AD}^{*} \mathrm{AE}^{*}\right)$ & 2.91 & 2.50 & 2.57 & 2.54 \\
\hline
\end{tabular}


other group. In fact, they do not differ much at all from the other groups on any of the measured variables except the CSA group which has significantly higher mean scores for belief about the future and time saved via logistics and customer service. People working in food nodes are not significantly advantaged under any of the scales we use, but they are worse than CSA on several.

When it comes to cooperation, the only group standing out is REKO. They spend significantly more time cooperating than all other groups, with the exception of food nodes.

As a whole, all of the scales examined show at least some statistically significant differences between the AFNs. With the exception of fair wages (mean total across all groups=2.46), all totals across groups are above the scale mean suggesting they are more happy than not, feel good about the future, cooperate, and think that they save time in their AFN on logistics and managing customer service.

\subsection{Regression analysis on happiness}

Before regressing our IVs on happiness, we checked and found that our data was suitable for using parametric analysis using procedures outlined by Hair et al. (1998). We then conducted five linear regression analyses - one for each group using the simultaneous enter method. Consequently, all groups were analysed using the same IVs to predict happiness (DV) and no attempts were made to optimize the models for a particular group. The results of these five regression models are in Table 6.

Starting with the REKO group, our model predicts $62 \%$ of variance in happiness (based on adjusted $\mathrm{R}^{2}$ ). Based on standardized Beta, the strongest predictor of happiness is 'future beliefs' $(P<0.001)$, followed by profitability $(P=0.01)$, fair wages $(P=0.02)$, and simplify customer service $(P=0.05)$. All other variables are non-significant at $P=0.05$ level. Interestingly, the Beta coefficient for profitability is negative, suggesting that being profitable detracts from their happiness.

For food nodes, all the variables entered into the model are non-significant with the exception of 'reduces logistics effort' $(P=0.05)$. In other words, those that believe logistics efforts are reduced, tend to be happier. Unlike the REKO group, being profitable has a positive effect on happiness, although it is not significant. Overall, this model explains $45 \%$ of happiness.

The model explaining happiness in farm stores also has only one significant predictor - future beliefs $(P<0.001$; beta 0.50 ). Overall, the model explains $46 \%$ of happiness based on adjusted $\mathrm{R}$ square. Two variables, 'reducing logistics efforts' and 'simplifying customer service' would be significant at around the $P=0.10$ level.

In the farmers market group, believing that the channel simplifies customer service $(P<0.001)$ and optimism for the future $(P=0.04)$ significantly predict happiness (adjusted $\mathrm{R}^{2}=0.56$ ).

Finally, we were unable to explain happiness in the CSA group as neither the model nor the predictors were significant.

\section{Discussion}

The first objective of this exploratory study was to develop a framework for identifying differences in SCM at the specific AFN level. The between group differences in SCM activities across the AFNs (Table 3 ) indicate that the structural properties of each AFN is distinct and can be meaningfully captured with the SCM framework developed. Across five AFNs, 28 significant paired differences were identified relating to how much time and energy was spent on 19 SCM activities (Table 3). The differences were related to managing returns, working with transportation partners, accepting orders from customers before delivery, maintaining supply to match customer lead time demands, understanding customer demand, ensuring a stable flow of products to customers, understanding what/when a customer buys so that it is in stock, managing 
Table 6. Linear regression results for different alternative food networks (AFN) and predictors of happiness. ${ }^{1}$

\begin{tabular}{|c|c|c|c|c|c|c|}
\hline AFN & Coefficients & Beta & $\mathbf{T}$ & Sig. & $\mathbf{r}$ & $\operatorname{adj.} R^{2}$ \\
\hline \multirow[t]{7}{*}{ REKO } & (Constant) & & -0.44 & 0.66 & $0.83 * * *$ & 0.62 \\
\hline & Fair wages & 0.32 & 2.45 & 0.02 & & \\
\hline & Profitable & -0.41 & -2.63 & 0.01 & & \\
\hline & Future beliefs & 0.80 & 5.70 & 0.00 & & \\
\hline & Reduces logistics effort & 0.02 & 0.13 & 0.90 & & \\
\hline & Simplify customer service & 0.28 & 2.06 & 0.05 & & \\
\hline & Cooperate with marketing & 0.13 & 1.14 & 0.27 & & \\
\hline \multirow[t]{7}{*}{ Food node } & (Constant) & & 2.12 & 0.05 & $0.75^{* *}$ & 0.45 \\
\hline & Fair wages & -0.15 & -1.01 & 0.32 & & \\
\hline & Profitable & 0.22 & 1.18 & 0.25 & & \\
\hline & Future beliefs & 0.19 & 1.12 & 0.28 & & \\
\hline & Reduces logistics effort & 0.44 & 2.06 & 0.05 & & \\
\hline & Simplify customer service & 0.11 & 0.54 & 0.59 & & \\
\hline & Cooperate with marketing & -0.09 & -0.65 & 0.52 & & \\
\hline \multirow[t]{7}{*}{ Farm store } & (Constant) & & 1.80 & 0.08 & $0.73 * * *$ & 0.46 \\
\hline & Fair wages & 0.20 & 1.27 & 0.21 & & \\
\hline & Profitable & -0.15 & -0.89 & 0.38 & & \\
\hline & Future beliefs & 0.50 & 3.09 & 0.00 & & \\
\hline & Reduces logistics effort & 0.22 & 1.68 & 0.10 & & \\
\hline & Simplify customer service & 0.21 & 1.60 & 0.12 & & \\
\hline & Cooperate with marketing & -0.02 & -0.14 & 0.89 & & \\
\hline \multirow[t]{7}{*}{ Farmers market } & (Constant) & & 2.87 & 0.01 & $0.78 * * *$ & 0.56 \\
\hline & Fair wages & -0.03 & -0.26 & 0.80 & & \\
\hline & Profitable & 0.19 & 1.19 & 0.24 & & \\
\hline & Future beliefs & 0.32 & 2.13 & 0.04 & & \\
\hline & Reduces logistics effort & -0.04 & -0.32 & 0.75 & & \\
\hline & Simplify customer service & 0.44 & 3.27 & 0.00 & & \\
\hline & Cooperate with marketing & 0.12 & 1.24 & 0.22 & & \\
\hline \multirow[t]{7}{*}{ CSA } & (Constant) & & 5.75 & 0.00 & 0.45 & -0.05 \\
\hline & Fair wages & 0.16 & 0.66 & 0.52 & & \\
\hline & Profitable & -0.29 & -1.08 & 0.30 & & \\
\hline & Future beliefs & 0.32 & 1.22 & 0.24 & & \\
\hline & Reduces logistics effort & 0.35 & 1.20 & 0.25 & & \\
\hline & Simplify customer service & -0.09 & -0.35 & 0.73 & & \\
\hline & Cooperate with marketing & -0.14 & -0.51 & 0.62 & & \\
\hline
\end{tabular}

${ }^{1}$ Dependent variable: happiness. Significant coefficient $P$-values bolded and italicized. Under column 'r' asterisks indicate significance of model based on $\mathrm{F}$ value $* * P<0.05, * * * P<0.001$. CSA $=$ community supported agriculture.

customer relations, matching offering and demand, communicating products to customers, and ensuring customers are satisfied.

Our second objective was to explore how differences in SCM activities at the specific AFN level contribute to socio-economic outcomes. We found evidence that the structural properties of AFNs (as measured through SCM activities) correlate with profitability and happiness. This is demonstrated in Table 4 where significant correlations between profitability and time/energy spent were found in 15 of the 19 SCM activities (Table 4). Moreover, the linear regression results (Table 6) indicate that happiness can be explained by reducing logistics effort or simplifying customer service and capture variance above and beyond other predictors such as profitability. However, this relationship did not extend to all the AFNs we studied. Reducing logistics 
effort was the strongest predictor of happiness in the food node network and potentially an important predictor in farm stores $(P=0.10)$. Similarly, simplifying customer service was the most important predictor of happiness in REKO and a significant predictor of happiness in farmer markets. Unexpectedly, profitability was negatively, yet significantly correlated with happiness in the REKO network and negatively correlated (but not significant) with farm stores and CSA.

Interestingly, the AFNs in this study generally claim to spend more effort and time (Table 3) on activities related to processing products, managing customer relations, and selling and communicating about products (than on more traditional logistics activities related to transportation, order management and meeting lead times), even though they do not seem to correlate with increased profitability (Table 4). The focus on processing might be explained by them historically being producers. The limited focus on logistics might be linked to this being a new exchange function (Clark, 1922) that small producers now have to handle due to their recent intermediation of the supply chain. The focus on managing customer relationships might be explained by producers that are motivated by developing more respectful and trustful relationships with customers (Tregear, 2011) and desire social interaction with customers (Fleischman and Craig, 2015). Among the different AFNs, we see (Table 3) that those having direct transactions with customers (farm store and farmers market) spend more time and effort on sales and marketing than those selling on subscription (CSA) or using an intermediating indirect platform (especially food node). On the other hand, AFNs with the shortest direct channel spend less on accepting orders, where e.g. REKO spends significantly more.

Some authors divide AFNs, based on their goals, e.g. those more instrumental and economically oriented (e.g. related to profitability), and those more idealistic oriented (Berti and Mulligan, 2016; Cleveland et al., 2014; Fleischman and Craig, 2015). With regards to happiness, our regression results seem to suggest more idealistic individuals across the AFNs (cf. Aksoy and Bayram Arli, 2020). Unlike previous research, profitability did not explain an increase in happiness (Blanchflower and Oswald, 1992). Across the groups, things like fair wages and belief about the future (which included opportunities to grow) were far better predictors (Table 6). In fact, profitability was only significant in one group (REKO) where it had a negative relationship with happiness. For some of the AFNs, happiness could be explained in terms of time savings, while in others, belief about the future or profitability explained most of the variance.

Although our CSA participants were significantly happier than all but one other AFN, we were not able to explain why. What we can say is that of all the AFN groups (Table 2), they are the only one dominated by men (66\%), they are the youngest on average, they reported earning the largest percentage of their overall sales from CSA and they are the least pluriactive. It is also noteworthy that CSA is the AFN type that from a SCM perspective seems most aligned with needing less time and energy. Presumably, the time and energy savings are spent on production, something that farmers in Sweden tend to prioritizing over things like marketing and market innovation (Klaesson et al., 2019). More research should try to establish what makes CSA producers happier to uncover their secret 'happiness sauce' - this may open up new ways of organizing AFN types, if not help us to identify other reasons individuals in AFNs are happy.

Previous research on AFNs has been criticized for aggregating AFNs based on point of delivery (Tregear, 2011) and missing factors explaining variety in their goal achievements. By studying the structural properties and SCM processes of each type of AFN we show that a SCM perspective is useful for understanding variance in profitability across AFNs. Common logistics reasoning can explain some observations e.g. regarding CSA as well as general differences between AFNs based on make-to-stock vs make-to-order logics. However, we acknowledge that adopting traditional SCM perspectives is challenging as they tend to cover a wide range of activities that are less relevant in an AFN context such as returns management. Also, SCM has traditionally focused on large companies with internal cross-functional issues as well as more complex relations with supply chain partners. But, to make AFNs economically sustainable there might be a need to find opportunities for scaling up certain activities by collaboration and coordination between producers - with or without using intermediaries. The SCM discipline, with its focus on coordination and collaboration between network partners, might here complement other disciplines studying AFNs. Although limited attention has so far 
been given to micro companies in the SCM discipline, recent work has recognized the need to study them (e.g. Bourlakis et al., 2014; Velázquez-Martínez and Tayaksi, 2020; Zaridis et al., in press) and the study of AFNs provides a useful context.

Our third and final objective was to explore differences in the demographic characteristics and attitudes of individuals working in each AFN. By investigating multiple AFNs at their specific, branded level, we found some interesting demographic and attitudinal differences that would otherwise have been obscured. Women formed the majority in all groups except CSA. The AFNs dominated by women and more specifically their overall business activity was more pluriactive in composition than the CSA group dominated by men who consisted of mostly primary producers. Similarly, there were large differences in the average age across AFNs where the older, more established AFNs such as farmer market and farm store, included the oldest participants in our sample and the emergent AFNs such as food node, REKO and CSA had the youngest. When differences in age and gender exist in an industry, questions of equality become important. Are women locked out of certain AFNs due to gender related factors or are they simply more attracted to certain types of AFN networks? Are older, primary producers missing out on opportunities in certain AFNs due to a lack of (e.g. knowledge) resources or are they simply drawn to more established ones because of risk preferences? These questions are important for future researchers to understand as they will help to break down barriers for those wishing to take part in AFNs.

Another argument for researching AFNs at their specific, what we call 'branded level', is that differences in socio-economic outcomes might be better explained by specific AFN type than by supply chain or other managerial choices. As an indication of this, we found large differences in the estimated hourly wage received ranging from 238 sek (circa \$23.80) for those in farmer market networks to just 85 sek $(\$ 8.50)$ in food node. What is striking about this variation is that it does not seem to be explainable based on newness or the reported importance of the channel to the overall business. Presumably, some AFNs have inherent economic advantages related to their typical value chain proposition, as this is common across industries (e.g. Porter, 1997). Moreover, previous research has found that performance by most companies can be explained by industry factors, however it is managerial differences in the most and least successful companies in an industry (Hawawini et al., 2003). That being the case, future research may benefit by not only conducting research at the 'branded' AFN level, but also by targeting the best and worst performing AFN companies to better understand how managerial differences influence socio-economic outcomes.

The descriptive statistics reveal that on average, overall sales and profitability in all the AFN channels investigated represented less than $50 \%$ of the overall companies' respective sales and profits. To be certain, there was considerable variation within each AFN, however the findings may indicate that for most, the AFN is not generating enough economic opportunity for individuals to work full-time in the channel. It would therefore be interesting for future research to separate between individuals participating part-time in AFNs and those that have managed to operate full-time to understand how it influences their ability to deliver on e.g. the 'sustainability promise'.

\section{Conclusions and limitations}

Recent calls in the AFN literature have encouraged researchers to disentangle the structural properties of AFNs from their socio-economic outcomes and to do this while embracing new theoretical perspectives and (quantitative) methods that, simultaneously, target multiple AFNs at their specific level (instead of aggregating different AFNs based on e.g. similarities in their organizational structure) (Michel-Villarreal et al., 2019; Tregear, 2011). We contribute to this call by developing a framework for identifying differences across five different types of AFNs while using a novel theoretical perspective that provided a framework for the quantification of how differences in SCM activities contribute to socio-economic outcomes such as profitability and happiness working in the AFN. 
Taken together, AFN studies that ignore structural differences when interpreting socio economic outcomes do so at their own peril (Tregear, 2011). Not only are there significant SCM differences between AFNs sharing e.g. similar points of customer exchange (Renting et al., 2003), we demonstrated that these differences relate to socio-economic outcomes such as profitability and happiness in unique ways.

It is important to emphasize that the sample in this study is Swedish, and based on convenience. This limits the generalizability of our findings, strictly speaking, to our sample. Nevertheless, we are unaware of any database that contains or tracks the total number of actors working with the AFNs we sampled. As a result, we were unable to do more than develop our own 'convenience' sample pieced together from secondary information and internet searches. This said, we feel more confident in stating that the differences we found across the AFNs reflect differences in the wider Swedish population. We base this on parallel, qualitative work we conducted in Sweden that reflects the quantitative findings in this study. Moreover, our operationalization of Lambert and Enz (2017) SCM processes resulted in 19 single items that exhibited low reliability and, at least for now, were not possible to reduce. Because of this, we did not perform some of our planned parametric tests (e.g. linear regression involving SCM processes and profitability) and instead turned to non-parametric, 'weak theory' tests of bivariate and partial correlations. Indeed, this was not due to a lack of effort on our part as we were not able to identify an equivalent operationalization of Lambert and Cooper (2000) tailored to AFNs. We believe this is an important gap that needs to be filled and encourage future researchers to develop and validate a model of supply chain management processes building from e.g. Lambert and Enz (2017) suitable for exploring AFNs and other small scale supply chains.

Nevertheless, we argue that in many ways the quality of data collected in this study is higher than previous comparative studies on AFNs which use aggregate, often secondary data to compare AFNs. By comparing AFNs at the level of a specific 'branded' supply chain, we found differences that previous research glossed over due to their confounding level of measurement. We also did this using a novel SCM perspective that provided a framework for understanding variance in socio-economic outcomes (i.e. profitability and happiness) that can inspire future research to investigate 'Why... some (AFN) initiatives exhibit problems whilst others appear to achieve virtuous goals? (Tregear, 2011: 423)'

To get long term sustainable AFNs, we think small scale producers should be both profitable and happy, spending their time and energy on what is important. Producers, not only those wanting to grow, could be helped to understand what time and energy should be invested in SCM, or if it is better to leverage other partners' capabilities to perform distribution functions. But the SCM domain must also develop and adopt their practices to this field where producers might measure cost differently, and idealistic motivations could override profitability in the quest for happiness. By this, we hope to have given both thoughts for food, and food for thought.

\section{Supplementary material}

Supplementary material can be found online at https://doi.org/10.22434/IFAMR2020.0193

Table S1. Item measurements and scales used in analysis.

\section{Acknowledgement}

This research study was funded by the Kamprad Family Foundation.

\section{References}

Agricultural European Innovation Partnership (EIP-AGRI) Focus Group. 2015. Innovative short food supply chain management. Final report. Available at: https://ec.europa.eu/eip/agriculture/en/publications/ eip-agri-focus-group-innovative-short-food-supply 
Aksoy, F. and N. Bayram Arli. 2020. Evaluation of sustainable happiness with sustainable development goals: structural equation model approach. Sustainable Development 28(1): 385-392.

Alderson, W. 1954. Factors governing the development of marketing channels. In: R. Clewett, (ed.) Marketing channels for manufactured products. Richard D. Irwin, Homewood, IL, USA, pp. 5-34.

Archor, S. 2011. The happiness advantage: the seven principles of positive psychology that fuel success and performance at work. Random House, New York, NY, USA.

Argyle, M. 1989. Do happy workers work harder? The effect of job satisfaction on work performance. In: R. Veenhoven (ed.) How harmfull is happiness? Consequences of enjoying life or not. Universitaire Pers Rotterdam, Rotterdam, the Netherlands, pp. 94-105.

Basiago, A.D. 1998. Economic, social, and environmental sustainability in development theory and urban planning practice. Environmentalist 19(2): 145-161.

Berti, G. and C. Mulligan. 2016. Competitiveness of small farms and innovative food supply chains: the role of food hubs in creating sustainable regional and local food systems. Sustainability 8(7): 616. https://doi.org/10.3390/su8070616

Blanchflower, D.G. and A.J. Oswald. 1992. Entrepreneurship, happiness and supernormal returns: evidence from Britain and the US. NBER Working Paper No. w4228, Available at SSRN: https://ssrn.com/ abstract $=478695$

Blanchflower, D.G. and A.J. Oswald. 2011. International happiness: a new view on the measure of performance. Academy of Management Perspectives 25(1): 6-22.

Bosworth, G. and J. Willett. 2011. Embeddedness or escapism? Rural perceptions and economic development in Cornwall and Northumberland. Sociologia Ruralis Journal of the European Society for Rural Sociology 51(2): 195-214.

Bourlakis, M., G. Maglaras, E. Aktas, D. Gallear and C. Fotopoulos. 2014. Firm size and sustainable performance in food supply chains: insights from Greek SMEs. International Journal of Production Economics 152: 112-130.

Brown, C. and S. Miller. 2008. The impacts of local markets: a review of research on farmers markets and community supported agriculture (CSA). American Journal of Agricultural Economics 90(5): 1298-1302.

Bucklin, L.P. 1960. The economic structure of channels of distribution. In: M.L. Bell (ed.) Marketing: $a$ maturing discipline. American Marketing Association, Chicago, IL, USA, pp. 379-385.

Carbone, V., A. Rouquet and C. Roussat. 2015. 'Carried away by the crowd': what types of logistics characterise collaborative consumption. In: $1^{\text {st }}$ International Workshop on Sharing Economy. 4-5 June 2010. Utrecht, the Netherlands. Available at: https://www.researchgate.net/profile/ChristineRoussat/publication/282075090_Carried_away_by_the_crowd_what_types_of_logistics_characterise_ collaborative_consumption/links/56def68a08aec8c022cf344d/Carried-away-by-the-crowd-whattypes-of-logistics-characterise-collaborative-consumption.pdf

Carter, C.R., Rogers, D.S. and T.Y. Choi. 2015. Toward the theory of the supply chain. Journal of Supply Chain Management 51(2): 89-97.

Chen, W. 2013. Perceived value of a community supported agriculture (CSA) working share. The construct and its dimensions. Appetite 62: 37-49.

Chouinard, H.H., T. Paterson, P.R. Wandschneider and A.M. Ohler. 2008. Will farmers trade profits for stewardship? Heterogeneous motivations for farm practice selection. Land Economics 84(1): 66-82.

Clark, F.E. 1922. Principles of marketing. McMillan, New York, NY, USA.

Cleveland, D.A., N.M. Müller, A.C. Tranovich, D.N. Mazaroli and K. Hinson. 2014. Local food hubs for alternative food systems: a case study from Santa Barbara County, California. Journal Rural Studies 35: 26-36.

European Union (EU). 2013. Regulation (EU) No 1305/2013 of the European Parliament and of the Council of 17 December 2013 on support for rural development by the European Agricultural Fund for Rural Development (EAFRD) and repealing Council Regulation (EC) No 1698/2005. EU, Brussels, Belgium.

Fleischman, D. and J. Craig. 2015. Exploring integration of non-economic goals into business models of small regional food enterprises: embedded value creation. Journal of New Business Ideas \& Trends 13(2): 39-56. 
Forssell, S. and L. Lankoski. 2015. The sustainability promise of alternative food networks: an examination through 'alternative' characteristics. Agriculture and Human Values 32(1): 63-75.

Gardner, J. and A. Oswald. 2002. Does money buy happiness? A longitudinal study using data on windfalls. Royal Economic Society Annual Conference 2002 81. Royal Economic Society, London, UK.

Hair Jr, J.F., W.C. Black, B.J. Babin, R.E. Anderson and R.L. Tatham. 1998. Multivariate data analysis. Prentice Hall, Upper Saddle River, NJ, USA, pp. 207-219.

Hawawini, G., V. Subramanian, V. and P. Verdin. 2003. Is performance driven by industry- or firm-specific factors? A new look at the evidence. Strategic Management Journal 24(1): 1-16.

Ilbery, B. and D. Maye. 2005. Alternative (shorter) food supply chains and specialist livestock products in the Scottish-English borders. Environment and Planning A: Economy and Space 37(5): 823-844.

Klaesson, J., S. Johansson, L. Bjerke and M. Allgurin. 2019. Innovationer i jordbruket och på Sveriges landsbygder. Jordbruksverket, Jönköping, Sweden.

Lambert, D.M. 2014. Supply chain management: processes, partnerships, performance, $4^{\text {th }}$ edition. Supply Chain Management Institute, Ponte Vedra Beach, FL, USA.

Lambert, D.M. and M.C. Cooper. 2000. Issues in supply chain management. Industrial Marketing Management 29(1): 65-83.

Lambert, D.M. and M.G. Enz. 2017. Issues in supply chain management: progress and potentials. Industrial Marketing Management 62: 1-16.

Martikainen, A., P. Niemi and P. Pekkanen. 2014. Developing a service offering for a logistical service provider - case of local food supply chain. International Journal of Production Economics 157: 318-326.

Michel-Villarreal, R., Hingley, M., Canavari, M. and I. Bregoli. 2019. Sustainability in alternative food networks: a systematic literature review. Sustainability 11(3): 859.

Porter, M.E. 1997. Competitive strategy. Measuring Business Excellence 1(2): 12-17.

Renting, H., T.K. Marsden and J. Banks. 2003. Understanding alternative food networks: exploring the role of short food supply chains in rural development. Environment and Planning A 35: 393-411.

Shaw, A.W. 1912. Some problem in market distribution. Quarterly Journal of Economics 26(4): 703-765.

Slater, S.F. and J.C. Narver. 1994. Does competitive environment moderate the market orientation-performance relationship? The Journal of Marketing 58(1): 46-55.

Stern, L.W. and A.I. El-Ansary. 1982. Marketing channels. Prentice Hall, Englewood Cliffs, NJ, USA.

Todorovic, V., M. Maslaric, S. Bojic, M. Jokic, D. Mircetic and S. Nikolicic. 2018. Solutions for more sustainable distribution in the short food supply chains. Sustainability 10(10): 3482. https://doi. org/10.3390/su10103481

Tregear, A. 2011. Progressing knowledge in alternative and local food networks: critical reflections and a research agenda. Journal of Rural Studies 27(4): 419-430.

Velázquez-Martínez, J.C. and C. Tayaksi. 2020. Supply chain management for micro and small firms in Latin America. In: H.T.Y. Yoshizaki, C. Mejía Argueta and M.G. Mattos (eds.) Supply chain management and logistics in emerging markets. Emerald Publishing Limited, Bingley, UK, pp. 197-214.

Warr, P. 2011. Work, happiness, and unhappiness. Psychology Press, London, UK.

Welch, B.L. 1951. On the comparison of several mean values: an alternative approach. Biometrika 38(3-4): 330-336.

Wubben, E.F.M., M. Fondse and S. Pascucci, 2013. The importance of stakeholder-initiatives for business models in short food supply chains: the case of the Netherlands. Journal on Chain and Network Science 13(2): 139-149.

Zaridis, A., I. Vlachos and M. Bourlakis. in press. SMEs strategy and scale constraints impact on agri-food supply chain collaboration and firm performance. Production Planning \& Control. https://doi.org/ $10.1080 / 09537287.2020 .1796136$ 
